\title{
Distribution of Plant Nutrient Elements and Carbon in Particle Size Fractions of Broiler Litter Ash
}

\author{
Eton E. Codling ${ }^{1, *}$ and Barbara Eickhoff ${ }^{2}$ \\ ${ }^{1}$ USDA-ARS-Environmental Management and Byproduct Utilization Laboratory, 10300 Baltimore Avenue, Beltsville, \\ MD 20705 \\ ${ }^{2}$ Research Station Agroscope ART, Reckenholzstrasse 191, 8046 Zürich, Switzerland
}

\begin{abstract}
An estimated 10.8 million tons of broiler litter and 3.0 million tons of turkey litter were produced in the United States in 2009. Poultry litter is a mixture of manure, bedding material (e.g. wood chips, sawdust, or straw), feathers, and spilled feed. Poultry litter contains high levels of $\mathrm{Ca}, \mathrm{N}, \mathrm{P}$, and $\mathrm{K}$, and is often applied as a fertilizer on fields in close proximity to poultry houses. Repeated poultry litter application to these fields can increase soil $\mathrm{P}$ to levels in excess of plant requirements, resulting in potential environmental risk. An alternative to land application of poultry litter is its use as a fuel in electricity generation. Ash from this process has been used as a fertilizer after sieving to $<1.27 \mathrm{~cm}$, with the larger fraction being discarded in landfills. The objective of this study was to determine the elemental composition of size fractions of broiler litter ash samples produced using a variety of burn durations and temperatures. Ten 2-kg broiler litter ash samples were collected from a biomass gasification test plant and sieved into five size fractions. Nutrients in the ash were extracted using Mehlich-1 solution. In most cases, nutrient concentrations were higher in the finer two fractions while $\mathrm{C}$ concentration was higher in the coarser $(>0.5 \mathrm{~mm})$ fractions. Nevertheless, the amount of $\mathrm{P}$ in the coarsest fraction ranged from 15 to 25 percent of the total extractable phosphorus in the ash. With such high $\mathrm{P}$ content in the coarse fraction, there is a potential of $\mathrm{P}$ leaching when this fraction is disposed of in landfills. We recommend that the coarse fraction should be crushed and mixed with the fine fractions before the ash is used as a fertilizer and soil amendment.
\end{abstract}

Keywords: Broiler litter ash, fractions.

\section{INTRODUCTION}

An estimated 10.8 million tons of broiler litter and 3.0 million tons of turkey litter were produced in the United States in 2009 [1]. Poultry litter (PL) is a mixture of manure, bedding material (e.g., wood chips, sawdust, or straw), feathers, and spilled feed [2]. PL may also contain some soil and rock from the poultry house floor. PL has a high content of nutrients such as $\mathrm{Ca}, \mathrm{N}, \mathrm{P}$, and $\mathrm{K}$, and is therefore often applied as fertilizer on fields near poultry houses [3]. Generally, more PL is produced than is needed to supply crop nutrients in the vicinity of poultry houses. PL application to fields with excess nutrients may result in potential environmental risk [4]. This can be through runoff and/or leaching, especially of $\mathrm{P}$ and $\mathrm{N}$, into surface and ground waters, resulting in compromised water quality through eutrophication [35]. In Pennsylvania, the application of PL to agricultural fields has been restricted in order to protect bodies of water. Proposed alternatives to the application of PL to fields with excess P include composting, pelletizing, or burning the PL, or transporting it to fields low in $\mathrm{P}$ that are further away. Transporting PL for very long distances would not be economically profitable due to transport costs.

*Address correspondence to this author at the USDA-ARS-Environmental Management and Byproduct Utilization Laboratory, 10300 Baltimore Avenue, Beltsville, MD 20705; Tel: 301-504-5708; Fax: 301-504-5048;

E-mail: eton.codling@ars.usda.gov
Because PL contains high-cellulose bedding material, it has been used as a fuel in electricity generation, both in pilot studies and in fully operational power plants [6]. In the UK, a PL-fueled power station has been in operation since 1992 [7], while in the U.S., a PL-fueled power plant was installed in Benson, Minnesota, in 2007 [8]. A small broiler litter combustion facility (Enginuity LLC) in Mechanicsburg, PA, is conducting pilot studies to determine the effects of temperature and duration of burning on energy production and on the ratio of ash to char in the combustion residue. It has been found that in energy production and the ash: char ratio also depend on whether the PL used was pre-dried before combustion, the speed at which PL moves through the furnace, and the $\mathrm{CO}_{2} / \mathrm{O}_{2}$ ratio in the combustion chamber. The poultry litter ash (PLA) that remains after combustion of PL is rich in the plant nutrients $\mathrm{Ca}, \mathrm{P}, \mathrm{Mg}$, and $\mathrm{K}$ and also contains $\mathrm{Zn}, \mathrm{Cu}$, and $\mathrm{Mn}$, making it potentially useful as a fertilizer $[9,10]$. Recycling of these plant nutrients is important, especially in the case of $\mathrm{P}$, of which resources are limited [11]. However, water soluble P in PLA is much lower than in commercial fertilizers or PL, as a result of the burning process [19]. The nutrient content and availability of PLA also depend on the type of bedding material and the ratio of bedding material to manure [12]. Because of the higher nutrient density of PLA relative to PL, the cost of transporting PLA is lower; thus PLA can be applied to fields further away from where it is produced [13]. PLA also has a high $\mathrm{pH}$ and 
Table 1. Combustion Parameters, pH, and Electrical Conductivity of the Broiler Litter Ash Samples

\begin{tabular}{|c|c|c|c|c|c|c|}
\hline Sample & Date & Time & $\begin{array}{l}\text { Duration of Burning } \\
\text { [min] }\end{array}$ & $\begin{array}{l}\text { Average Burning Temperature } \\
\qquad\left[{ }^{\circ} \mathbf{C}\right]\end{array}$ & pH & $\begin{array}{c}\mathrm{EC} \\
\mathrm{mS} / \mathrm{cm}\end{array}$ \\
\hline 1 & $8 / 22 / 2011$ & $4: 33 \mathrm{pm}-8: 30 \mathrm{pm}$ & 237 & 778 & $11.7 \mathrm{~d} \dagger$ & $55.1 \mathrm{ab}$ \\
\hline 3 & $8 / 23 / 2011$ & $7: 25 \mathrm{am}-10: 45 \mathrm{am}$ & 200 & 732 & $11.6 \mathrm{e}$ & $59.5 \mathrm{ab}$ \\
\hline 4 & $8 / 23 / 2011$ & $12: 50 \mathrm{pm}-4: 10 \mathrm{pm}$ & 200 & 704 & $13.3 \mathrm{a}$ & $47.1 \mathrm{ab}$ \\
\hline 6 & $8 / 21 / 2011$ & $3: 10 \mathrm{pm}-5: 45 \mathrm{pm}$ & 155 & 804 & $11.9 \mathrm{cde}$ & $55.8 \mathrm{ab}$ \\
\hline 7 & $8 / 23 / 2011$ & $3: 10 \mathrm{am}-7: 25 \mathrm{am}$ & 255 & 771 & $12.1 \mathrm{bc}$ & $57.8 \mathrm{ab}$ \\
\hline 8 & $8 / 22 / 2011$ & 4:00 am - 9:56 am & 356 & 746 & $12.0 \mathrm{bcd}$ & $47.5 \mathrm{ab}$ \\
\hline 9 & $8 / 23 / 2011$ & $10: 45 \mathrm{am}-12: 50 \mathrm{pm}$ & 125 & 670 & $12.4 \mathrm{~b}$ & $53.2 \mathrm{ab}$ \\
\hline 10 & $5 / 5 / 2011$ & $6: 30 \mathrm{am}-9: 00 \mathrm{am}$ & 150 & 601 & $12.0 \mathrm{bcd}$ & $44.3 \mathrm{~b}$ \\
\hline
\end{tabular}

$\dagger$ Means within columns having a letter in common are not significantly different at $\mathrm{P}<0.05$ using Duncan multiple range test.

may be useful as a soil liming agent. The liming effects of PLA may be affected by the bedding material. It has been shown that wood ash can increase soil $\mathrm{pH}$ and benefit plant growth [14], so bedding material containing sawdust or wood chips may have a similar effect. An additional advantage of using PLA on soil is the potential of carbon sequestration when PLA that is rich in char (charcoal) is applied to soil. Application of char to soil provides a long-term sink for atmospheric carbon dioxide in the terrestrial ecosystem [15]; [16]. Char can also improve soil physical and biological properties and enhance plant growth [17, 18]. A potential concern in using PLA as a fertilizer is the arsenic (As) content of the ash, because As is added to poultry feed to control intestinal parasites and to increase weight gain, and it is found in the manure $[20,21]$. However, this may be a problem of the past, as some poultry producers have already stopped using As. Recently; Maryland became the first state in the U.S. to ban the feeding of As to poultry [22].

The broiler litter ash used in this experiment was from a small pilot broiler litter combustion facility (Enginuity LLC) in Mechanicsburg, PA. At this facility, broiler litter ash (BLA) is sieved using a $1.27-\mathrm{cm}$ sieve to produce an ash fraction that can be applied with farm machinery, while the BLA fraction $>1.27 \mathrm{~cm}$ is discarded in a landfill. The objective of this study was to determine the concentration of plant nutrients and carbon in five size fractions of ten broiler litter ash samples produced with a range of burn durations and temperatures.

\section{MATERIALS AND METHODS}

\section{Broiler Litter Ash Collection, Processes and Analysis}

Ten 2-kg BLA samples were collected from a biomass gasification test plant (Enginuity LLC) in Mechanicsburg, PA. The ten BLA samples represent four different burning days. The BLA samples were stored in Ziploc plastic bags until use. Information on the temperature and duration of combustion for each sample is presented in Table $\mathbf{1}$.

Each BLA sample was sieved into five fractions with a range of particle sizes (Table 2). For analysis, a sub-sample of $10 \mathrm{~g}$ was taken from each size fraction of each sample.
Table 2. Particle Sizes of the Broiler Litter ash Fractions Separated by Screening

\begin{tabular}{|c|c|}
\hline Fraction & Size in $\mathbf{~ m m}$ \\
\hline \hline 1 & $>2.38$ \\
\hline 2 & $<2.38$ to 2.00 \\
\hline 3 & $<2.00$ to 0.50 \\
\hline 4 & $<0.50$ to 0.25 \\
\hline 5 & $<0.25$ \\
\hline
\end{tabular}

Sub-samples were ground using a mortar and pestle to a size of $<0.25 \mathrm{~mm}$ and analyzed with three replicates. The $\mathrm{pH}$ was determined 1:2 (BLA to de-ionized water, by volume) slurry after $1 \mathrm{hr}$ using a glass electrode [23]. Electrical conductivity was also determined by using an Orion model 160 conductivity meter in a 1: 2 (BLA to de-ionized water, by volume) slurry after $1 \mathrm{hr}$. Total carbon (C) concentration was measured using a rapid CS analyzer (Elementar, Hanau, Germany). Thirty $\mathrm{mg}$ of ground BLA sample and $30 \mathrm{mg}$ of conditioner (Tungsten VI and Wolfram VI oxides) were wrapped in tin foil prior to measurement. The detection limit of the instrument was $0.01 \mathrm{mg} \mathrm{C}$, corresponding to a $\mathrm{C}$ concentration of $0.03 \%$ in a $30-\mathrm{mg}$ sample. Near-total $\mathrm{P}$ concentration was measured in Mehlich-1 extracts. The Mehlich-1 extracting method [24] was used to determine the near-total $\mathrm{P}$ concentration in the BLA fractions. A 0.1-g sample of ground $(<25 \mathrm{~mm})$ BLA was placed in a $250-\mathrm{ml}$ Erlenmeyer flask and $100 \mathrm{ml}$ of Mehlich-1 solution $(0.025 \mathrm{~N}$ $\mathrm{H}_{2} \mathrm{SO}_{4}+0.05 \mathrm{~N} \mathrm{HCl}$ ) was added. Samples were shaken for 5 min on a horizontal shaker at $200 \mathrm{rpm}$. Extracts were filtered through Whatman No. 42 filter paper and stored until analysis. Phosphorus (P) concentration was analyzed with two methods: colorimetrically and by inductively coupled plasma optical emission spectrometry (ICP-OES; PerkinElmer, Wellesley, MA) with scandium as the internal standard. Colorimetric $\mathrm{P}$ determination was done by the ascorbic acid method [24]. Absorption was measured at $880 \mathrm{~nm}$ with an UV/VIS Lambda 25 spectrometer (PerkinElmer, Wellesley, $\mathrm{MA})$. Potassium $(\mathrm{K})$, calcium $(\mathrm{Ca})$, and magnesium $(\mathrm{Mg})$ were also measured in Mehlich-1 extract using ICP-OES. 


\section{Statistical Analysis}

Statistical analysis of the data was performed using PCSAS [25]. Data were analyzed by one-way ANOVA to test the significance of differences in mean elemental concentrations between size fractions of each ash sample. Separation of means was done using Duncan's multiple-range test [26].

\section{RESULTS AND DISCUSSION}

\section{pH and Electrical Conductivity}

There were no significant differences in $\mathrm{pH}$ or electrical conductivity (EC) of BLA between size fractions within samples. Therefore, $\mathrm{pH}$ and EC results for each sample were averaged over size fractions. With the exception of samples 4 and 5 , which had higher $\mathrm{pH}$ values, there was little difference in BLA pH between samples (Table 1). However, samples 4 and 5 did not have higher burn durations or temperatures, which contrasted with the results of a previous study that observed increased $\mathrm{pH}$ of BLA with increasing burning temperature [27]. Burning temperature and burning duration did not influence EC of BLA (Table 1). Although samples 1, 2, 3, 6, and 7 had the highest EC values, the differences were not significant.

\section{Total Carbon}

Within ash samples, there was some relationship between the $\mathrm{C}$ concentration of BLA and its particle size. In samples $1,3,7$, and 9 , for example, $\mathrm{C}$ concentration decreased with decreasing particle size, whereas for samples $2,6,8$, and 10 the highest $\mathrm{C}$ concentration was found in the fraction $<2-0.5$ $\mathrm{mm}$, which is in the middle of the range (Table 3). Among the ten samples, sample 9 had the highest $\mathrm{C}$ concentration in each size fraction. The high $\mathrm{C}$ concentration in sample 9 may have resulted from its shorter burning time (125 minutes) and from its having the second lowest average burning temperature $\left(670{ }^{\circ} \mathrm{C}\right)$, which resulted in less ash and more char for this sample (Table 1). Samples 2, 5, and 7 had low C concentrations, probably as a result of their relatively high burning times and temperatures. Sample 8 , with a similar burning temperature as samples 2,5 , and 7 but a longer burning duration, had a higher $\mathrm{C}$ concentration, with values of $47.6,34.5,53.7$, and $95.2 \mathrm{mg} \mathrm{g}^{-1}$ for samples $2,5,7$, and 8 , respectively. The high level of $\mathrm{C}$ in sample 8 could have been influenced by the type of bedding material and the ratio of bedding material to manure, which generally differ in their flammability and/or C content. Mante and Agblevor [28] reported that the $\mathrm{C}$ concentration of wood based bedding material is generally higher than that of manure. Finally, the composition of poultry manure often varies between farms due to different management practices $[29,12]$. The application of carbon-rich BLA to soil could contribute to the sequestration of carbon. Lehmann et al. [15] reported that application of char to soil is a long-term sink for atmospheric carbon dioxide in the terrestrial ecosystem. Char can also improve soil physical and biological properties and enhance plant growth when applied to soil $[17,18]$.

\section{Extractable Nutrients}

Because there was very little difference between P concentration determined colorimetrically and that determined by ICP-OES, P determined by ICP-OES was used for this manuscript. Averaged over fractions, sample 8 had the high- est $\mathrm{P}$ concentration (392 $\mathrm{mg} \mathrm{g}^{-1}$ ) while sample 9 had the lowest $\left(302 \mathrm{mg} \mathrm{g}^{-1}\right)$. The lower level of $\mathrm{P}$ observed in sample 9 may have been a consequence of its higher $\mathrm{C}$ concentration (Table 3). Faridullah et al. [27] reported increased $\mathrm{P}$ concentration but decreased C concentration of PLA with increasing burning temperature. Adams [30], however, observed no change in $\mathrm{P}$ with increasing temperature. Although there were significant differences in $\mathrm{P}$ concentration between some size fractions within each ash sample, all fractions had at least $60 \mathrm{mg} \mathrm{P} \mathrm{g}^{-1}$, with the exception of the coarsest fraction of sample 9 (Table 3). The coarser fractions $(>2.0 \mathrm{~mm}$; fractions 1 and 2 ) generally had lower $\mathrm{P}$ concentrations compared to the finer fractions $(<0.5 \mathrm{~mm}$; fractions 4 and 5). Nevertheless, when the content of $P$ in the size fractions was examined (data not shown), the differences were slight. For example, $\mathrm{P}$ content of the coarsest fraction, expressed as percent of the total $P$ in the sample, ranged from 14.8 to 25.0 across the ten samples, compared to a range of 20.6 to 25.0 percent for the finest fraction. The $\mathrm{P}$ content of the coarsest fraction could potentially contribute to environmental problems such as eutrophication if it is discarded in landfills. For most samples, $\mathrm{Ca}$ concentration was higher in the fractions $<$ $0.50 \mathrm{~mm}$, although for samples 1,4 , and 5 , the highest $\mathrm{Ca}$ level was in the coarsest fraction (Table 3). The higher $\mathrm{Ca}$ levels generally found in the fine fractions may have resulted from the large quantity of soluble $\mathrm{Ca}$ that is fed to broilers and then secreted in the manure [31,32]. Averaged over the five fractions, samples 4 and 5 had significantly higher $\mathrm{Ca}$ concentrations compared to the other samples (Table 3). In all cases, $\mathrm{K}$ concentration was generally higher in the finer fractions $(<2.0 \mathrm{~mm})$ than in the coarse fraction $(>2.38 \mathrm{~mm})$. With the exception of sample $4, \mathrm{Mg}$ concentration was generally higher in the finer fractions than in the coarser fractions (Table 3). When averaged over fractions, nutrients concentrations were in the order $\mathrm{Ca}>\mathrm{K}>\mathrm{P}>\mathrm{Mg}$ for all samples. The high $\mathrm{Ca}$ to $\mathrm{P}$ ratio observed in BLA resulted from the higher level of $\mathrm{Ca}$, compared to that of $\mathrm{P}$, in the broilers' diet. Ansar et al. [33] state that a dietary Ca:P ratio of 1:0.5 is essential for the performance of various functions in the birds, and that a deficiency or excess of one can interfere with the proper utilization of the other. Although concentrations of $\mathrm{P}, \mathrm{Ca}, \mathrm{K}$, and $\mathrm{Mg}$ were lower in the coarsest fraction, its content of these elements was still substantial. Instead of being sieved out and discarded, as it is currently, it should be crushed and mixed with the finer fractions for use as a fertilizer. Dumping or land filling the coarse fraction of BLA would result in a loss of valuable plant nutrients and potentially contribute to the eutrophication of surface water.

\section{CONCLUSIONS}

Analysis of 10 broiler litter ash (BLA) samples revealed large variations in their concentrations of plant nutrients and carbon, possibly resulting from variations in broiler litter source and combustion parameters. For most BLA samples, carbon concentration was highest in the larger size fractions $(>0.5 \mathrm{~mm})$, while concentrations of the plant nutrients $\mathrm{P}, \mathrm{Ca}$, $\mathrm{K}$, and $\mathrm{Mg}$ were highest in the finer size fractions $(<0.5$ $\mathrm{mm})$. Nevertheless, the amount of $\mathrm{P}, \mathrm{Ca}, \mathrm{K}$, and $\mathrm{Mg}$ in the coarsest $(>2.38 \mathrm{~mm})$ fraction of all BLA samples was high enough that disposal of these materials in landfills could result in the leaching of valuable plant nutrients and the eutrophication of water bodies. Crushing the coarse fraction 
Table 3. Results of One-Way ANOVA between Particle Size Fractions of each Broiler Litter ash Sample for the Elements C, P, Ca, $\mathrm{K}$, and $\mathrm{Mg}$

\begin{tabular}{|c|c|c|c|c|c|c|c|c|c|c|}
\hline $\begin{array}{c}\text { fraction } \\
{[\mathrm{mm}]}\end{array}$ & $\begin{array}{c}\text { Sample } 1 \\
{[\mathrm{mg} / \mathrm{g}]}\end{array}$ & $\begin{array}{c}\text { Sample } 2 \\
{[\mathrm{mg} / \mathrm{g}]}\end{array}$ & $\begin{array}{c}\text { Sample } 3 \\
{[\mathrm{mg} / \mathrm{g}]}\end{array}$ & $\begin{array}{c}\text { Sample } 4 \\
{[\mathrm{mg} / \mathrm{g}]}\end{array}$ & $\begin{array}{c}\text { Sample } 5 \\
{[\mathrm{mg} / \mathrm{g}]}\end{array}$ & $\begin{array}{c}\text { Sample } 6 \\
{[\mathrm{mg} / \mathrm{g}]}\end{array}$ & $\begin{array}{c}\text { Sample } 7 \\
{[\mathrm{mg} / \mathrm{g}]}\end{array}$ & $\begin{array}{c}\text { Sample } 8 \\
{[\mathrm{mg} / \mathrm{g}]}\end{array}$ & $\begin{array}{c}\text { Sample } 9 \\
{[\mathrm{mg} / \mathrm{g}]}\end{array}$ & $\begin{array}{c}\text { Sample } 10 \\
{[\mathrm{mg} / \mathrm{g}]}\end{array}$ \\
\hline \multicolumn{11}{|c|}{ Carbon } \\
\hline$>2.38$ & $34.2 \mathrm{a} \dagger$ & $7.4 \mathrm{~d}$ & $45.4 \mathrm{a}$ & $23.6 \mathrm{~d}$ & $7.5 \mathrm{a}$ & $20.2 \mathrm{~d}$ & $12.2 \mathrm{a}$ & $14.6 \mathrm{~d}$ & $189.7 \mathrm{a}$ & $46.9 \mathrm{c}$ \\
\hline$<2.38-2.0$ & $23.0 \mathrm{~b}$ & $9.5 \mathrm{c}$ & $31.7 \mathrm{~b}$ & $24.1 \mathrm{~d}$ & $7.4 \mathrm{a}$ & $30.9 \mathrm{~b}$ & $11.9 \mathrm{ab}$ & $19.0 \mathrm{c}$ & $152.5 \mathrm{~b}$ & $76.0 \mathrm{~b}$ \\
\hline$<2.0-0.5$ & $20.6 \mathrm{c}$ & $11.2 \mathrm{a}$ & $32.8 \mathrm{~b}$ & $30.8 \mathrm{c}$ & $5.4 \mathrm{~b}$ & $37.0 \mathrm{a}$ & $11.2 \mathrm{~b}$ & $27.1 \mathrm{a}$ & $153.5 \mathrm{~b}$ & $84.4 \mathrm{a}$ \\
\hline$<0.5-0.25$ & $18.3 \mathrm{~d}$ & $10.0 \mathrm{~b}$ & $22.4 \mathrm{c}$ & $50.5 \mathrm{~b}$ & $6.1 \mathrm{~b}$ & $28.6 \mathrm{c}$ & $10.8 \mathrm{~b}$ & $21.0 \mathrm{~b}$ & $130.1 \mathrm{c}$ & $63.5 \mathrm{~b}$ \\
\hline$<0.25$ & $14.0 \mathrm{e}$ & $9.5 \mathrm{bc}$ & $18.9 \mathrm{~d}$ & $58.1 \mathrm{a}$ & $8.1 \mathrm{a}$ & $19.5 \mathrm{~d}$ & $7.6 \mathrm{c}$ & $13.5 \mathrm{e}$ & $79.6 \mathrm{~d}$ & $27.7 \mathrm{~d}$ \\
\hline \multicolumn{11}{|c|}{ Phosphorus } \\
\hline$>2.38$ & $77.7 \mathrm{ab}$ & $75.0 \mathrm{~b}$ & $68.6 \mathrm{c}$ & $61.6 \mathrm{c}$ & $68.7 \mathrm{~cd}$ & $75.5 \mathrm{ab}$ & $73.3 \mathrm{~b}$ & $62.8 \mathrm{c}$ & $45.0 \mathrm{c}$ & $71.0 \mathrm{~b}$ \\
\hline$<2.38-2.0$ & no sample & $75.7 \mathrm{~b}$ & $72.3 \mathrm{~b}$ & $58.2 \mathrm{~d}$ & $63.9 \mathrm{~d}$ & $74.9 \mathrm{~b}$ & $75.4 \mathrm{ab}$ & $75.3 \mathrm{~b}$ & $56.1 \mathrm{~b}$ & $60.3 \mathrm{~d}$ \\
\hline$<2.0-0.5$ & $76.3 \mathrm{~b}$ & $78.8 \mathrm{a}$ & $78.9 \mathrm{a}$ & $66.6 \mathrm{~b}$ & $73.4 \mathrm{bc}$ & $78.9 \mathrm{a}$ & $80.7 \mathrm{ab}$ & $79.9 \mathrm{ab}$ & $62.9 \mathrm{bc}$ & $66.9 \mathrm{c}$ \\
\hline$<0.5-0.25$ & $77.0 \mathrm{ab}$ & $78.6 \mathrm{a}$ & $79.3 \mathrm{a}$ & $72.7 \mathrm{a}$ & $77.7 \mathrm{a}$ & $78.7 \mathrm{a}$ & $79.3 \mathrm{a}$ & $86.1 \mathrm{a}$ & $67.9 \mathrm{a}$ & $71.6 \mathrm{~b}$ \\
\hline$<0.25$ & $79.7 \mathrm{a}$ & $80.4 \mathrm{ab}$ & $79.3 \mathrm{a}$ & $71.4 \mathrm{a}$ & $75.6 \mathrm{ab}$ & $79.7 \mathrm{a}$ & $80.7 \mathrm{a}$ & $87.8 \mathrm{a}$ & $70.6 \mathrm{a}$ & $78.0 \mathrm{a}$ \\
\hline \multicolumn{11}{|c|}{ Calcium } \\
\hline$>2.38$ & $140.8 \mathrm{a}$ & $128.2 \mathrm{~b}$ & $122.4 \mathrm{c}$ & $168.5 \mathrm{a}$ & $163.8 \mathrm{a}$ & $125.8 \mathrm{bc}$ & $131.8 \mathrm{bc}$ & $113.2 \mathrm{c}$ & $105.6 \mathrm{c}$ & $125.0 \mathrm{~b}$ \\
\hline$<2.38-2.0$ & no sample & $127.5 \mathrm{~b}$ & $130.0 \mathrm{~b}$ & $167.6 \mathrm{a}$ & $145.5 \mathrm{~b}$ & $128.1 \mathrm{c}$ & $130.8 \mathrm{c}$ & $131.5 \mathrm{~b}$ & $124.9 \mathrm{~b}$ & $109.0 \mathrm{~d}$ \\
\hline$<2.0-0.5$ & $132.7 \mathrm{~b}$ & $135.4 \mathrm{ab}$ & $137.3 \mathrm{a}$ & $157.9 \mathrm{~b}$ & $145.4 \mathrm{~b}$ & $133.1 \mathrm{ab}$ & $137.4 \mathrm{abc}$ & $137.5 \mathrm{~b}$ & $123.7 \mathrm{~b}$ & $118.7 \mathrm{c}$ \\
\hline$<0.5-0.25$ & $133.2 \mathrm{~b}$ & $137.1 \mathrm{a}$ & $139.0 \mathrm{a}$ & $150.3 \mathrm{c}$ & $144.6 \mathrm{~b}$ & $133.5 \mathrm{a}$ & $135.9 \mathrm{ab}$ & $147.9 \mathrm{a}$ & $128.3 \mathrm{~b}$ & $125.2 \mathrm{~b}$ \\
\hline$<0.25$ & $135.5 \mathrm{~b}$ & $138.0 \mathrm{a}$ & $142.0 \mathrm{a}$ & $149.2 \mathrm{c}$ & $149.1 \mathrm{ab}$ & $133.9 \mathrm{ab}$ & $135.5 \mathrm{a}$ & 146.9 a & $146.2 \mathrm{a}$ & $134.0 \mathrm{a}$ \\
\hline \multicolumn{11}{|c|}{ Potassium } \\
\hline$>2.38$ & $84.7 \mathrm{c}$ & $101.5 \mathrm{c}$ & $98.8 \mathrm{c}$ & $78.4 \mathrm{c}$ & $77.3 \mathrm{c}$ & $93.9 \mathrm{c}$ & $91.0 \mathrm{~d}$ & $65.0 \mathrm{c}$ & $71.7 \mathrm{~d}$ & $86.2 \mathrm{~b}$ \\
\hline$<2.38-2.0$ & no sample & $104.5 \mathrm{bc}$ & $104.8 \mathrm{c}$ & $78.4 \mathrm{c}$ & $91.4 \mathrm{~b}$ & $107.7 \mathrm{bc}$ & $97.4 \mathrm{bcd}$ & $89.6 \mathrm{~b}$ & $81.6 \mathrm{c}$ & $91.6 \mathrm{~d}$ \\
\hline$<2.0-0.5$ & $109.6 \mathrm{a}$ & $111.6 \mathrm{~b}$ & $112.0 \mathrm{~b}$ & $92.0 \mathrm{~b}$ & $91.1 \mathrm{~b}$ & $109.8 \mathrm{~b}$ & $107.9 \mathrm{c}$ & $100.1 \mathrm{~b}$ & $92.0 \mathrm{~b}$ & $94.4 \mathrm{c}$ \\
\hline$<0.5-0.25$ & $114.8 \mathrm{a}$ & $122.4 \mathrm{ab}$ & $120.1 \mathrm{ab}$ & $106.6 \mathrm{a}$ & $102.4 \mathrm{ab}$ & $115.8 \mathrm{ab}$ & $112.4 \mathrm{~b}$ & $119.7 \mathrm{a}$ & $102.5 \mathrm{ab}$ & $108.7 \mathrm{~b}$ \\
\hline$<0.25$ & $118.7 \mathrm{a}$ & $124.5 \mathrm{a}$ & $119.5 \mathrm{a}$ & $108.2 \mathrm{ab}$ & $108.2 \mathrm{a}$ & $123.2 \mathrm{a}$ & $117.4 \mathrm{a}$ & $122.3 \mathrm{a}$ & $105.4 \mathrm{a}$ & $117.2 \mathrm{a}$ \\
\hline \multicolumn{11}{|c|}{ Magnesium } \\
\hline$>2.38$ & $28.5 \mathrm{~d}$ & $29.6 \mathrm{c}$ & $28.2 \mathrm{~d}$ & $48.2 \mathrm{a}$ & $35.0 \mathrm{ab}$ & $27.8 \mathrm{~d}$ & $31.2 \mathrm{c}$ & $27.4 \mathrm{c}$ & $34.8 \mathrm{c}$ & $25.0 \mathrm{~d}$ \\
\hline$<2.38-2.0$ & no sample & $29.3 \mathrm{c}$ & $30.3 \mathrm{c}$ & $47.5 \mathrm{a}$ & $37.2 \mathrm{~b}$ & $31.5 \mathrm{c}$ & $31.3 \mathrm{c}$ & $30.2 \mathrm{bc}$ & $37.3 \mathrm{~b}$ & $26.5 \mathrm{c}$ \\
\hline$<2.0-0.5$ & $29.2 \mathrm{c}$ & $30.2 \mathrm{c}$ & $31.6 \mathrm{bc}$ & $38.9 \mathrm{~b}$ & $33.4 \mathrm{a}$ & $32.9 \mathrm{~b}$ & $33.6 \mathrm{~b}$ & $30.4 \mathrm{bc}$ & $32.9 \mathrm{~d}$ & $25.7 \mathrm{~d}$ \\
\hline$<0.5-0.25$ & $31.7 \mathrm{~b}$ & $32.8 \mathrm{~b}$ & $33.1 \mathrm{bc}$ & $36.3 \mathrm{c}$ & $33.4 \mathrm{a}$ & $35.4 \mathrm{~b}$ & $33.8 \mathrm{~b}$ & $37.0 \mathrm{a}$ & $35.0 \mathrm{c}$ & $28.5 \mathrm{~b}$ \\
\hline$<0.25$ & $36.0 \mathrm{a}$ & $38.4 \mathrm{a}$ & $37.3 \mathrm{a}$ & $38.7 \mathrm{~b}$ & $39.5 \mathrm{a}$ & 39.9 a & $38.2 \mathrm{a}$ & $40.7 \mathrm{a}$ & $44.2 \mathrm{a}$ & $35.7 \mathrm{a}$ \\
\hline
\end{tabular}

$\dagger$ Means within columns and elements having a letter in common are not significantly different at $\mathrm{P}<0.05$ using Duncan multiple range test.

and mixing it with the finer fractions before their utilization as a fertilizer would reduce the potential for nutrient loss to the environment.

\section{ACKNOWLEDGEMENTS}

The authors sincerely acknowledge Mr. Mooney from Enginuity LLC for providing the broiler litter ash for this study and Mebrat Gesese for her technical assistance in conducting the experiment.

\section{REFERENCES}

[1] Perera R, Perera P, Vosky RP, Darby P. Potential of using poultry litter as a feedstock for energy production. Working Paper 2010; \# 88 .
[2] Sharpe RR, Scomber HH, Harper LA, Endale DM, Jenkins MB, Franzluebbers AJ. Ammonium volatilization form surface-applied poultry litter under conservation tillage management practices. J Environ Qual 2004; 33:1183-8.

[3] Pote DH, Way TR, Kleinman PJA, et al. Surface application of poultry litter in pasture and no-till soils. J Environ Qual 2011; 40: 402-11.

[4] Edwards DR, Daniel TC. Environmental impacts of on-farm poultry waste disposal - a review. bioresource tech; 1992; 41: 9-33.

[5] Sharpley A N, Moyer B. Phosphorus form in manure and compost and their release during simulated rainfall. J Environ Qual 2000; 29:1462-9

[6] Santoianni DA, Bingham MF, Woodard DM, Kinnell JC. Power from animal waste - economic technical and regulatory landscape in the united states. J EUEC 2008; 2: 1-37.

[7] Energy Power Resources Limited. http://www.eprl.co.uk/assets/eye/detail.html. [Accessed 3/1/12]. 
[8] Fibrowatt LLC. http://www.fibrowattusa.com/ Accessed 3/2/12.

[9] Codling E, Chaney RL, Sherwell J. Poultry litter ash as a potential phosphorus source for agricultural crops. J Environ Qual 2002; 31: 954-61.

[10] Faridullah MI, Yamamoto S, Ahmad Z, Endo T, Honna T. Extractability and bioavailability of phosphorus from soils amended with poultry litter and poultry litter ash. J Food Agric Environ 2009; 7 : 692-7.

[11] Bachmann S, Eichler-Löbermann B. Soil phosphorus pools as affected by application of poultry litter ash in combination with catch crop cultivation. Comm Soil Sci Plant Anal 2010; 41:1098111.

[12] Eck HV, Stewart BA. Manure In Soil amendments and environmental quality. Rechcigl JE, Ed. Boca Raton FL: Lewis Pub 1995; pp.169-98.

[13] PPES-2. Comprehensive engineering and socioeconomic assessment of using poultry litter as a primary fuel at the eastern Correctional institution cogeneration facility. Volume I 2000; (esm.versar.com/pprp/eci/1-VolumeI-IIPDF.pdf 3/23/12).

[14] Krejsl JA, Scanlon TM. Evaluation of beneficial use of wood-fired boiler ash on oat and bean growth. J Environ Qual 1996; 25: 950-4.

[15] Lehmann J, Gaunt J, Rondon M. Bio-char sequestration in terrestrial ecosystems -a review. Mitigation Adapt Strategies Glob Change 2006; 11: 403-27

[16] Ogawa M, Okimori Y,Takahashi F. Carbon sequestration by carbonization of biomass and forestation: three case studies. Mitigation Adapt Strategies Glob Change 2006; 11: 429-44.

[17] Glaser B, Lehmann J, Zech W. Amelioration physical and chemical properties of highly weathered soils in the tropics with charcoal- A review. Biol Fertil Soils 2002; 35: 219-30

[18] Lehmann J, da Silva JP Jr, Steiner C, NehlsT, Zech W, Glaser B. Nutrient availability and leaching in an archaeological Anthrosol and a Ferrasol of the central Amazon basin fertilizer, manure and charcoal amendments. Plant Soil 2003; 249: 343-57.

[19] Codling E. Laboratory Characterization of Extractable Phosphorus in Poultry Litter and Poultry Litter Ash. Soil Sci 2006; 171: 85864.

[20] Miller CV, Hancock TC, Denver JM. Environmental Fate and Transport of Arsenical Feed Amendments for Animal Agriculture. American Geophysical Union, 2000; Spring Meeting. May 30-June
3, 2000, Washington, DC. http://va.water.usgs.gov/GLOBAL/Abst/hancock agu 2000.htm. Accessed 3/5/12.

[21] Lasky T, Sun W, Kadry A, Hoffman MK. Mean total arsenic concentrations in chicken 1989-2000 and estimated exposures for consumers of chicken. Environ Health Perspect 2004; 112:18-21.

[22] Wheeler T. Maryland ban on arsenic in chicken feed to spread? http://articles.baltimoresun.com/2012-05-22/features/bal-bmgomalley-to-sign-law-banning-arsenic-in-chicken-feed-

201205221 roxarsone-levels-of-inorganic-arsenic-chicken-feed

The Baltimore Sun, May, 2012.

[23] McLean EO. Soil $\mathrm{pH}$ and lime requirement. In Method of Soil Analysis; part 2, $2^{\text {nd }}$ ed. Page A.L, Ed.; ASA and SSSA: Madison, Wisconsin 1982; pp. 199-224.

[24] Kuo S. Phosphorus. In D.L. Sparks (ed.) Methods of soil analysis. Part 3. Chemical methods. SSSA Book Ser. 5. ASA and SSSA Madison WI 1996; pp. 689-919.

[25] SAS. Proc mixed $92^{\text {ed }}$. SAS Institute Cary, NC 2008.

[26] Steel R GD, Torrie JH. Duncan's New Multiple Range Test: Principles and procedures of Statistics. New York: McGraw-Hill, 1980; pp. 187-8.

[27] Faridullah MI, Yamamoto S, Irshad M, Uchiyama T, Honna T. Phosphorus fractionation in chicken and duck litter burned at different temperatures. Soil Sci 2008; 173: 287-95.

[28] Mante OD, Agblevor FA. Influence of pine wood shavings on pyrolysis of poultry litter. Waste Manag 2010; 30: 2537-47

[29] Dao TH, Zhang H. Rapid Composition and Source Screening of Heterogeneous Poultry Litter by X-Ray Fluorescence Spectrometry. Ann Environ Sci 2007; 1: 69-79.

[30] Adams ZC. Comparison of broiler litter ash with reagent grade material as sources of plant nutrients. Master's Thesis. Auburn University, Auburn Alabama 2005.

[31] Casteel SN, Maguire RO, Israel DW, Crozier CR, Brake J. Broiler breeder manure phosphorus forms are affected by diet location, and period of accumulation. Poult Sci 2011; 90: 2689-96.

[32] Fernandes JIM, Lima FR, Mendonca JR, Mabe I, Albuquerque, Leal PM. Relative bioavailability of phosphorus in feed and agricultural phosphates for poultry. Poult Sci 1999; 78: 1729-36.

[33] Ansar M, Khan SA, Chaudhary ZI, Mian NA. Tipu MY, Rai M F. Effect of high dietary calcium and low phosphorus on urinary system of broiler chicks. Pak Vet J 2004; 24: 113-6.

Received: September 19, 2012

Revised: October 31, 2012

Accepted: November 13, 2012

(C) Codling et al.; Licensee Bentham Open.

This is an open access article licensed under the terms of the Creative Commons Attribution Non-Commercial License (http://creativecommons.org/licenses/by-nc/3.0/) which permits unrestricted, non-commercial use, distribution and reproduction in any medium, provided the work is properly cited. 